South African Review of Sociology

\title{
Local meanings of a sport mega-event's legacies: Stories from a South African urban neighbourhood
}

\section{Maikel Waardenburg, Marjolein van den Bergh \& Frank van Eekeren}

To cite this article: Maikel Waardenburg, Marjolein van den Bergh \& Frank van Eekeren (2015) Local meanings of a sport mega-event's legacies: Stories from a South African urban neighbourhood, South African Review of Sociology, 46:1, 87-105, DOI: 10.1080/21528586.2014.989664

To link to this article: $\underline{\text { http://dx.doi.org/10.1080/21528586.2014.989664 }}$

\section{曲 Published online: 15 May 2015.}

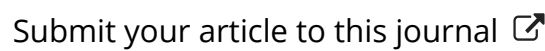

Џ Article views: 73

Q View related articles $\square$

View Crossmark data ¿ 


\title{
LOCAL MEANINGS OF A SPORT MEGA-EVENT'S LEGACIES: STORIES FROM A SOUTH AFRICAN URBAN NEIGHBOURHOOD
}

\author{
Maikel Waardenburg, Marjolein van den Bergh and \\ Frank van Eekeren \\ Utrecht University, School of Governance \\ Correspondence address: M.Waardenburg@uu.nl
}

\section{ABSTRACT}

Studies on sport mega-events and their legacies often seem only loosely connected to local experiences. Stories on sport mega-event legacy appear as a setting-thescene or function as a reference to illustrate specific types of legacy. However, stories themselves are never the primary focus in these studies. What is generally lacking from these studies is an interpretive perspective, giving voice to ordinary citizens' everyday experiences of legacies in mundane aspects of their lives and their local environment. The article aims to add an analysis of stories to the existing body of knowledge as an innovative way of interpreting sport mega-events' legacies. We introduce a narrative ethnographic approach for studying sport mega-event legacy, by looking at the way stories and narrative analysis are used to conceptualise legacy in the sociological subfield of ageing-studies. In our case study we show how citizens from one Johannesburg township make sense of the legacy of the 2010 FIFA World Cup one year after the event, by analysing people's stories about two sport-for-development projects. We conclude that local residents

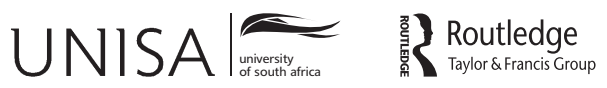

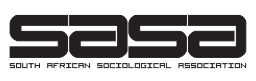

South African Review of Sociology 
of the township of Alexandra perceive changes in public safety and the image of Alexandra as the most important positive legacy of the 2010 FIFA World Cup. At the same time they take a critical stance towards the World Cup's legacy, because personal situations and community structures were often disrupted, rather than improved. We maintain that a narrative ethnographic approach provides extensive accounts about sport mega-event legacies, which help to better understand the different faces of sport mega-events' legacies at a micro level.

Keywords: sport mega-event, legacy, storytelling, narrative ethnography, FIFA World Cup

\section{INTRODUCTION}

Long after the final whistle of the 2010 FIFA World Cup, Alexandra [a Johannesburg neighbourhood] took international centre stage with the official opening of the Football for Hope Centre. The centre is the 16th of 20 centres to be built on the continent as part of the 20 Centres for 2010 campaign. This was the official campaign of the 2010 FIFA World Cup, which was aimed at creating 20 centres for education, public health and football across Africa. The launch was attended by South African Football Association (SAFA) president Dr Danny Jordaan, FIFA secretary general Jérôme Valcke, Deputy Minister of Sport and Recreation Gert Oosthuizen, and other delegates. Speaking at the launch, Jordaan stated that the centre would provide the youth of the community with the care they needed and would also help to tackle some of their challenges. He also thanked FIFA for building these centres. 'I want to thank those who have worked hard to make this dream a reality and I am very proud to be a part of this', Jordaan said.

James Donald of Grassroots Soccer, a global non-governmental organisation, said the centres were not about finding talent, but about using football to link local children to services. 'This centre for example will be helping children learn about tough challenges in their community, about gender-based violence, about HIV, about drug and alcohol abuse. We will be helping them work with local volunteers, to build relationships with caring adults and help connect them to services', he said. FIFA's Valcke declared he was happy and proud of what they had achieved. He said the 2010 World Cup was not just about having a successful world cup, 'it was to bring hope to the world and to bring the community together' (Ben 2013: 1).

The above story is one of many that are told in the build-up to, during and after a sport mega-event. Media, government officials, event organisers and business representatives present stories that provide the audience a legacy narrative. In the example above, it is a narrative of increased possibilities of sport participation as a means for developing healthy and socially strong communities. This is a typical sport-related social type of legacy. More visible stories in the media concern large infrastructure projects related to the hosting of a sport mega-event, such as the development of a new airport or a 
highway (Newton 2009). In everyday discourse, as well as in the media, stories about sport mega-event legacy abound. However, these stories are seldom the central focus of scholarly interest on sport mega-event legacy. Sport mega-events' legacies have been a notable research topic over the last twenty years among sport management scholars and sport sociologists. More than a dozen publications have been devoted to conceptualising legacy. The contribution of Preuss (2007) particularly serves as a landmark to subsequent studies on the topic. Scholars of sport mega-events and their legacies develop frameworks for understanding legacies (Chappelet 2012; Hunter and Rowles 2005; Lienhard and Preuss 2014; Preuss 2007), study the economic or social successes of the event at a macro level (Bob and Swart 2010; Doherty 2009; Heere et al. 2013; Kim and Petrick 2005), analyse political behaviour of stakeholders (Misener and Mason 2009), or critique the practice of hosting a sport mega-event (Cottle 2011; Doherty 2013; Newton 2009). Several authors signalled a lack of studies rooted in local experiences (see Cornelissen et al. 2011). An exception to this is a study by Korean anthropologist Hae-joang (2004), who observes in local manifestations 'unexpected nationalism' among Koreans as a result of their national team's success at the selfhosted 2002 FIFA World Cup. His study is a fine, but rare example of how local stories help in understanding the way in which legacy is constructed and rooted in a specific local context. Stories can do all kinds of work (Forester 1993; Van Hulst 2013). For one, they convey meaning to a specific event or situation. Stories thus provide us information on how people perceive the legacy of a sport mega-event in its local context. Furthermore, stories have effects in social interaction, and as a result stories themselves reconstruct legacies (Riessman 2008). Some storytellers explicitly use stories for political mobilisation and change, while others use stories to express empathy with or their belonging to a specific community. Storytelling thus serves certain ends.

What is further lacking from previous studies is an interpretive perspective, giving voice to ordinary citizens' everyday experience of legacies in mundane aspects of their lives and their local environment. In this article, we look at this understudied aspect of sport mega-events' legacy by focusing on storytelling as a theoretical lens to local experiences with two sport-for-development projects in Alexandra, South Africa. Such sport-for-development projects are typical for the way sport mega-event organisers and their sponsors try to enact a lasting legacy of the event, thus positioning the sport megaevent as a legitimate aspect of development policy (Darnell 2012).

The article adds a focus on local meanings as a way of interpreting the legacy of the event to the existing body of knowledge. It aims to describe the complexity of sport mega-event legacy at a local level, through using and analysing local stories. What we wanted to know empirically is which stories people tell about the legacy of the 2010 FIFA World Cup and how these stories help in understanding and conceptualising the sport mega-event legacy. To put it differently, how do local citizens make sense of sport mega-events' legacies and what does this focus on local stories add to understanding the concept of sport mega-event legacy? We answer these questions by analysing legacy 
stories of local residents about two sport-for-development projects in Alexandra: the FIFA Football for Hope Centre; and the Kia Street Soccer Tournament. The sections that follow (1) give a short review of the literature on sport mega-events' legacies and the way the concept of legacy has been studied in other sociological sub-disciplines, (2) clarify our methodological approach and choices of methods, (3) report the main findings of the field work, and (4) discuss our findings and relate them to the debate on sport mega-events' legacies.

\section{LEGACY RESEARCH}

The concept of legacy has been developed most significantly in sport management studies, particularly as a result of the increased attention legacy has received from hosting nations and cities and event-owners, such as the International Olympic Committee (IOC) and the Fédération Internationale de Football Association (FIFA). The development of the concept over the past two decades in academic sport studies started by growing scholarly interest during the early 1990s and increased at the beginning of the $21 \mathrm{st}$ century (Preuss 2007). The term is now widely used among sport and event managers and among sport academics, although there is little agreement on the definition, types or dimensions of legacy. Despite this lack of clarity there is a widespread urge among government officials and event organisers to differentiate between types of legacy and to measure these types on their own merits.

Sport sociologists and economists studying the legacies of sport mega-events distinguish between several types of legacy (see Alegi and Bolsmann 2013; Cashman 2003; Gratton and Preuss 2008; Cornelissen et al. 2011; Shausteck de Almeida et al. 2013). Based on the 2010 FIFA World Cup held in South Africa, Cornelissen et al. (2011) discuss six types of legacy: economic, infrastructural, sociocultural, political, sport development and environmental legacies. What becomes clear from these discussions on legacy types is that sport mega-event organisers try to incorporate more and more as the legacy of the event, and that academics seem to follow steadily. Chappelet (2012: 78) righteously argues that it seems futile to continue to propose typologies of legacy 'since it is possible to segment all that remains after a mega (sporting) event almost $a d$ infinitum'.

More recently, legacy has been conceptualised in dimensions rather than types (see Agha et al. 2012; Chappelet 2012; Preuss 2007). Chappelet (2012) introduces three dimensions. To begin with, there are tangible and intangible legacies. For the former, one may think of improved infrastructure and sport facilities; the latter may refer to increased national pride or the experience that a sport mega-event can be hosted on African soil. A second dimension is rooted in a distinction between territorial and personal legacy. The former refers, for instance, to displacement areas such as Blikkiesdorp, a relocation camp made up of corrugated row-upon-row iron shacks, located in Delft township on the outskirts of Cape Town, South Africa. The latter refers to individual experiences of citizens, volunteers, athletes and spectators. A third dimension Chappelet distinguishes 
concerns the sport and non-sport relatedness of the legacy. A renewed sport policy, increases in sport participation and new sport facilities are all sport specific legacies, while, Chappelet argues, a new airport or improved personal skills are not directly related to sport. In a similar vein, Preuss (2007) highlights tangible/intangible, planned/ unplanned and negative/positive as three dimensions of legacy.

Next to a discussion on what sport mega-event legacy means, there is a discussion on how sport mega-event legacy can or should be researched and measured. As the legacy of sport mega-events is still a highly ambiguous concept, both politically and academically, the measurement is complicated. Hosting sport mega-events is therefore often criticised by political action groups who stress negative connotations of legacy, such as public debt, 'white elephants' (under-used facilities) and disrupted communities. Many studies focus on the short-term economic impact of sport mega-events, more specifically related to event tourism (e.g. Burgan and Mules 1992; Lee and Taylor 2005), employment impacts (e.g. Bohlmann and Van Heerden 2005) and urban development (e.g. Chalkley and Essex 1999). Preuss argues these studies are too fragmented, as ' $[t]$ he measurement of legacy has to consider all changes caused by a mega event over time' (Preuss 2007: 212). Moreover, because of their focus on short-term impacts, Preuss argues that these studies do not contribute to understanding an event's legacies. Instead, he argues for a bottom-up approach that measures all changes of local structures due to the event (Preuss 2007). However, most studies on sport mega-event legacy do not measure all changes. Rather, they measure a specific type of legacy (e.g. Heere et al. 2013; Kim et al. 2006).

What these discussions of legacy make clear is that legacy is a heterogeneous concept referring to multiple, distinguishable aspects. Depending on the context and the actors involved, certain aspects are emphasised. Therefore, it can hardly be surprising that hosting cities, IOC or FIFA stress mostly the positive, economic and tangible aspects of a sport mega-event legacy. Their narratives of legacy often emphasise such aspects, because these ultimately legitimise organising the event. Notwithstanding the notion that a sport mega-event has significant macro-economic and macro-social impacts, we agree with Cornelissen et al. (2011: 316) who argue, 'it is important to consider the various event impacts in relation to the context in which they occur'. We take context to be the citizens' local neighbourhoods. We argue that legacy can be further understood by examining how those citizens narrate legacy through their stories about the way the 2010 FIFA World Cup affected their lives and local neighbourhood.

\section{LEGACY AND STORYTELLING}

The concept of legacy also has roots away from sport management, most notably in the sociological subdiscipline of ageing studies (Hunter and Rowles 2005, Polkinghorne 2000). Here, legacy takes the meaning of a personal bequest, rather than the impersonal meaning it has in studies on sport mega-events (Cashman 2003). Scholars in this 
field also developed typologies. Hunter and Rowles (2005), for instance, differentiate between three overlapping types of legacy: biological legacy (e.g. passing on genes, organ donation), material legacy (e.g. passing on heirlooms or a diary) and legacy of values (e.g. honesty, treating people well, independence or uniqueness). They signal the legacy of values to be the most important of the three:

In order to conclude a life story there seems to be a need to create a moral of the story. One of the most important things was to come up with a nugget of wisdom or insight - an expression of the essence of the self-created over a lifetime that could be passed along to future generations. This nugget might be a way of illustrating the meaning one had created in one's life (Hunter and Rowles 2005: 344).

In other words, stories function as a means to make sense of one's personal experiences in life. Storytellers create a narrative understanding of what has happened, or use narrative to achieve certain ends. This may not always be done deliberately and consciously:

The ends that are being achieved may be utterly obscure to those whose narratives they are. Rather, the claim is simply that narratives, as sensemaking tools, inevitably do things - for people, for social institutions, for culture, and more (Freeman 2002: 9).

In ageing studies, legacy has been empirically conceptualised largely by examining stories told by old, ill, or dying persons (Hunter and Rowles 2005; Hunter 2007; Moore et al. 2006). Stories thus function as the empirical foundation for the conceptualisation of legacy.

It is the significance of stories in the ageing-studies' understanding of legacy that we want to introduce to the field of sport sociology and sport management, not their specific conceptualisation or typologies of legacy. Through stories, we can get a sense of what people encountered during and after the event, what they (dis)-valued and how they made sense of that (Van Hulst 2013). In addition, stories offer insight into the complexity of organising (Chen 2012), adding detail and depth to understanding (different types of) legacy. In other words, 'stories are more than an outline of incidents; they are placed in a narrative context that gives meaning to the human experience of temporality, spatiality and personal action' (Hunter and Rowles 2005: 328). In this regard, legacy is what people perceive it to be and the meaning of legacy is communicated through people's stories related to the specific event.

Stories on legacy capture the complexity of human interaction and feeling through a self-constructed presentation of meaning and beliefs. In other words, storytelling is not simply the practice of sharing experiences in a chronological order, but a narrative structured meaning-making practice. Further, stories always convey a moral stance (Freeman 1993); to tell a story in a certain way is to choose what to include and exclude 'based on fundamental beliefs, values and ideals one holds' (Hunter and Rowles 2005: 329), thereby making a moral narrative choice. In a similar vein, people construct their own stories of sport mega-event legacies by selecting meaningful experiences of that 
event. In doing so they create meaningful accounts of and make more understandable for themselves what happened around the 2010 FIFA World Cup.

Stories about the legacy of the 2010 FIFA World Cup and many other sport megaevents abound. These stories are to be found in traditional newspaper articles (e.g. Dimeo and Kay 2004), op-eds, formal policy documents, documentaries, on personal blogs (e.g. constitutionallyspeaking.co.za) and on social media platforms, such as Facebook and Twitter, and in everyday street-corner conversations. While stories about the legacy of sport mega-events seem to pop up almost everywhere, academics seem only modestly interested in them as sources for knowledge accumulation about sport mega-events' legacies. As noted in the previous section, studies on the subject are highly focused on theoretically conceptualising and empirically measuring legacy. In their effort to get a grip on the concept, academics tend to surpass informal stories about legacy as an empirical source. Stories on sport mega-events' legacies appear as a setting-thescene (e.g. Curi et al. 2011; Horne 2004) or function as a reference to illustrate specific types of legacy (e.g. Chappelet 2012; Preuss 2007), but stories themselves are never the primary focus in these studies.

Stories are hinted at, specifically when scholars refer to sentiments among the public. Consider this fragment from Horne (2004), for example:

Pumping public money into the construction of huge sport stadiums does not find unanimous favour in Japan. Since the 1998 Winter Olympics in Nagano, which for various reasons failed to reproduce the atmosphere of the Tokyo Olympics [in 1964] and the mystical experience of national rebirth, negative sentiments against boosterism abound among many of the inhabitants of the debt-ridden prefectures in Japan. The unfulfilled promises of reviving the economy and reinstalling trust in the future have contributed to widespread pessimism and a dismissive stance against the construction of mega-sites for just a single occasion (Horne 2004: 1240).

In the fragment the author hints several times at stories about sport mega-events legacies, when he refers to 'negative sentiments', 'widespread pessimism' and 'a dismissive stance', but throughout the article these stories are typically not explicated. Similar arguments can be made for other academic work on the subject (e.g. Curi et al. 2011; Newton 2009). By only indirectly referring to stories, scholars mystify their meanings, functions and the contribution they can have for understanding the complex phenomenon of sport mega-events' legacies. This is a shortcoming, because studying stories has proven to be very worthwhile for scholars of ageing studies in trying to get a grip on the concept of legacy.

In the remainder of this article we try to demystify stories by focusing on the narratives everyday stories of sport mega-event legacies convey. We further highlight in what way these local stories differ from official and ceremonial narratives to be encountered in policy documents and public speeches of government officials and event organisers. 


\section{METHODS}

Using an ethnographic and narrative approach (Riessman 2008), we show how South African citizens from one Johannesburg neighbourhood experience the legacy of the FIFA World Cup 2010 one year after the event. To grasp the stories in the first place, an ethnographic approach is suitable, because it allows us to acquaint ourselves with local inhabitants and their surroundings. By adopting the role of the professionally interested observer, rather than the formal interviewing researcher, our hope was that informants trusted us with their stories.

Narrative analysis is concerned with the analysis of stories, in oral or written form, that reveal someone's experiences (Fischer 2003). The narrative approach allows us to keep the stories presented to us intact, rather than breaking all stories into component themes (Riessman 2008). This way, we can understand more fully what is being told and what the message of the stories is. In our analysis of those stories we concentrated on their overarching storyline, that is, what the personal stories shared in their way of interpreting the legacy of the 2010 FIFA World Cup.

One of the authors was part of a research group of three that stayed for five weeks in May and June 2011 in Alexandra, one of Johannesburg's poorest neighbourhoods. During her fieldwork she had informal talks with some forty local inhabitants, and conducted interviews with fifteen persons. The focus of the fieldwork was initially on the Football for Hope Centre. Through the stories of local inhabitants special attention arose around the KIA Street Soccer tournament as well. Both are seen as tangible forms of 2010 FIFA World Cup legacies. By analysing the stories of the local inhabitants, we show diverse and paradoxical meanings attached to the legacy of the 2010 FIFA World Cup for local citizens.

We collected a special sort of stories as they were told to foreign young (white) researchers assisted by a local guide. They differed from stories inhabitants tell one another, because the context inevitably touched more upon the setting of an interview, rather than a natural conversation, although we tried to organise the setting as informally as possible. The difference between our conversations and conversations inhabitants had among themselves was mostly due to our research purpose and our social distinction from and unfamiliarity with the local inhabitants and local situations. As Van Hulst (2013: 636) found in his study on storytelling in police stations, 'interviews produced clearly different types of stories from those that could be found in other, more "natural" contexts'. In interpretive research, this issue of representation is not viewed as a problem for the reliability of the project. The way in which the researcher is aware of the issue and reflects upon it is key to the trustworthiness of the project (Schwartz-Shea and Yanow 2012). In our case, we reflected daily on our observations and interviews through field notes and conversations with one another. Furthermore, we openly discussed our interpretations of local stories with several local inhabitants, most notably our personal guide. 
With several local inhabitants we spoke more than once and because of that we developed a more durable relationship with some of them. We will refer to these more familiar informants by using their names. People we spoke to occasionally, we refer to by their function or profession. As mentioned above, we asked one of the locals to be our guide. The use of a guide has a certain kind of influence. He or she has some leverage in steering the researchers' attention. For instance, the second case presented in the result section, the KIA Street Soccer tournament, was introduced to us by our guide. However, when we were introduced to this project by our guide, we immediately discussed the relevance of the project for our research purpose and decided to sustain our observations of it.

In storytelling 'a speaker connects events into a sequence that is consequential for later action and for the meanings that the speaker wants the listener to take away from the story' (Riessman 2008: 3). In order to grasp the narrative of stories, we concentrated on the plot of the story, that is, how incidents were ordered, which and how characters were identified in these incidents and where incidents were situated. Our analysis thus focused on the order of events, characters and the setting of the events. We coded our data with these narrative themes. From those codes we developed tentative narratives. The next section discusses our findings and explicitly focuses on narratives of two sportfor-development projects that were initiated in 2010 as side-events of the World Cup.

\section{RESULTS: STORIES FROM ALEXANDRA}

As with all stories, local stories about legacy we encountered were structured around a beginning, a middle and a closing section and presented a meaningful plot. In general, the first time we spoke to a person about the legacy of the World Cup, he or she would start with descriptions about situations or events during the period that the World Cup was held in South Africa and make a comparison about the situation before and after the event. We interpreted this as the beginning of a story. The middle of the story consisted of personal experiences and related emotions. Often these experiences were situated in Alexandra, and connected to daily routines. For instance, a local bar owner would typically refer first to changes in Alexandra at large and then continue the story to describe changes he experienced in his bar, that in his eyes had to be explained through the World Cup. The end of the story consisted mostly of an evaluation, expressing one or more reflecting sentences on what was learned from the presented story.

In the following sections we present how different meanings about the legacy of the 2010 FIFA World Cup are presented in local stories on two sport-for-development projects: the FIFA Football for Hope Centre and the Kia Street Soccer Tournament. We start by briefly describing the general goals of those projects. We then continue with a more detailed analysis of stories about the two sport-for-development projects. These stories concern both tangible and intangible forms of legacy. The stories reveal a nuanced, and in some ways paradoxical interpretation of the legacy of the World Cup. 


\section{1. (In)accessibility and disruption: The FIFA Football for Hope Centre}

Alexandra is situated on the banks of the Jukskei River. In addition to its original, relatively well-built houses, it also has a large number (estimated at more than 20000 ) of informal dwellings or 'shacks'. The main streets are paved and crowded minibustaxis drive through the area. Deeper inside the neighbourhood, it is crammed with shacks. According to a local public servant, the area has a high population density: 'There are 800000 people living in $10 \mathrm{~km}^{2}$, most of the homes containing five or six people' (Moodley Interview, 25 May 2011). From Alexandra, you can see Sandton, the wealthiest suburb in South Africa: 'the difference between the haves and the haves-not couldn't be bigger' (Moodley, Interview 25 May 2011). Residents refer to a perceived feeling of unsafety by explaining that Alexandra is seen as a dangerous neighbourhood for outsiders, as well as for residents. As a result it used to be very uncommon that outsiders came into the area and people from Alexandra were not used to seeing outsiders. Residents tell us stories about the unsafety they experienced themselves: the need to stay at home after sunset, or the danger women experienced when walking on their own, because they were at risk of sexual assault or rape. The neighbourhood is shunned by those who do not have to be there, because it is known to be unsafe.

In anticipation of the 2010 FIFA World Cup, FIFA started its campaign 20 Centres for 2010. The aim of this campaign was to achieve positive social change through football by building 20 Football for Hope Centres for public health, education and football across Africa. Alexandra was chosen to be one of the neighbourhoods that would receive a Football for Hope Centre. In November 2013, the centre was finally opened. The organisation chosen to run this centre was Grassroot Soccer, a nonprofit organisation that 'uses the power of soccer to educate, inspire, and mobilize communities to stop the spread of HIV' (Grassroot Soccer 2013). As noted above, the Football for Hope Centre had not yet been built in Alexandra during the World Cup in 2010. Therefore, FIFA organised a Football for Hope Festival, just before the start of the World Cup, as a kick-off event for the World Cup and the future Football for Hope Centre. For this festival, a small artificial football pitch with a stand was built in the centre of the neighbourhood, close to a community centre and a primary school. Youth from less fortunate backgrounds from all over the world were invited in Alexandra for the festival, to celebrate the World Cup and to participate in a two-week programme. They were divided into football teams, each with a coach from Alexandra, and competed in a football tournament with the main focus on fair play.

When we arrive for the first time, the festival terrain is closed. Security personnel need to open the gates for us. The terrain consists of a small football field, a stand around it and a community centre next to it, which already existed before the festival was held. Moshe, the coordinator of the festival, tells us that the pitch used during the festival was donated by FIFA to the city of Johannesburg. According to the municipality, the pitch is used intensively. The responsible official of the municipality states: 'They 
left the field for the schools, that's the legacy. FIFA paid for the renovation of the field. That's also the legacy.' (Ngwenya, Interview 1 June 2011).

However, we find the terrain closed and empty several times when we visit the neighbourhood; children play football on the streets next to it. Local residents tell us that the football field is rarely used. Even the people who work in the community centre, which is located next to the festival site, tell us that the field is not used often. A volunteer expresses his view: 'In my opinion, there are not enough kids playing on the field. I hope there will be more programmes' (Anonymous, volunteer community centre, 11 May 2011).

The main threshold experienced by the residents of Alexandra is that permission for use of the field must be granted at a municipality office. Moshe explains that this office is located at the other side of Johannesburg. According to him, residents of Alexandra do not have the money or the capacity to go there. He experiences this form of bureaucracy as a barrier for sport participation and a cause for the empty field.

The (in)accessibility of the football pitch acts as a major theme in residents' stories. This is not only due to the closed gates, the empty fields or the official permission necessary to enter the site. It is also a theme because the current site is a temporary one, a new Football for Hope Centre will be built at the eastern border of Alexandra. According to several volunteers, this will not serve the purpose of sport participation, because this new site is in an isolated area and therefore harder and less safe for children to reach.

Another theme addressed in stories about the FIFA Football for Hope Festival concerns the disruption of local voluntary participation. Ayanda, a former volunteer of Play Soccer South Africa (PSSA), an international NGO active in sport and development, explains that there were more people willing to volunteer during the festival than needed. Active volunteers at PSSA, like Ayanda, were asked to be a coach during the Football for Hope Festival. She explains that every team at the festival got a team leader from Alexandra. But there were fewer team leaders necessary than the number of volunteers at PSSA. For her, this created a feeling of competition among volunteers. The people who were not selected, felt excluded, explains Ayanda. Another person thought the selection was based on the personal network of the coaches: 'They wanted to be a part of it, there was only place for the people they knew' (Anonymous, volunteer community centre, 20 May 2011). When the Football for Hope festival was over, the volunteers who could not participate in the event, felt excluded. This caused a separation within the organisation: 'The separation wasn't somebody's fault. Some people thought they were less good, so the collaboration didn't work anymore' (Ayanda, Interview 31 May 2011).

Residents' stories further revealed that the legacy of the 2010 FIFA World Cup is interpreted in rather paradoxical ways. While the ways in which the project develops and is organised are questioned, citizens also add positive elements about the project in their stories. Residents state that Alexandra received a lot of (media) attention because of the Football for Hope project. Some argue that this kind of attention would normally go to 
Soweto. When residents talk about the improvement of the image of the neighbourhood, they perceive this to be a result of the attention generated through the World Cup, and more specifically the sport-for-development projects in their neighbourhood. People often mention the World Cup as the most important trigger for this change. Our guide, Ace, says she notices the difference between the period before and after the World Cup: 'Before, no one knew this township, or only in a bad way. Now we can prove that it's safe here and that Alexandra can arrange things', referring to the Football for Hope Festival. Because of such projects, the establishment visited Alexandra (see also Doherty 2013). Inhabitants were not used to this: 'Other events were in Jo'burg, not here. It was never here. Now people from overseas came, Zuma [president of South Africa] came. And I have never seen so many white people in my township' (Anonymous, student community journalism centre, Interview 20 May 2011). Some residents also tell us that they had hoped to gain economically from the programmes and the outsiders that came into the neighbourhood. But 'there was only business for the luckiest ones' (Anonymous, local bar owner, 18 May 2011). Although tourists would not sleep in Alexandra, or drink much in the bars in the neighbourhood, residents state that during the World Cup, people from outside Alexandra did visit the neighbourhood. As a consequence residents now experience an increased perception of safety and a feeling of pride.

\subsection{A lack of commitment: the Kia Street Soccer Tournament}

Another sport-for-development project that was launched in Alexandra in 2010 is the Kia Street Soccer Tournament. The Kia Street Soccer Tournament was initially set up for children from impoverished areas in Johannesburg, Pretoria, Durban and Cape Town. The first edition was during the period of the 2010 FIFA World Cup. In 2011 it returned as an annual event, organised by the non-governmental organisation Sporting Chance. The size of the project has increased to 6000 players in 2013, in 40 regions around South Africa. The Kia Street Soccer programme targets children under the age of 13. The programme aims to get these children active, develop their self-esteem, and educate them about the importance of staying active, healthy nutrition and goal-setting (Sporting Chance 2013). The development of these critical life skills was stated as a major target of the Kia Street Soccer programme.

During our stay in Alexandra in 2011, the Kia Street Soccer Tournament was in full swing. Several inhabitants told us about the current tournament and the edition in 2010. Ace, our guide, eventually took us there. This provided us the opportunity to observe several match days and talk with players and coaches involved in the programme.

During seven weeks, a select group of children was able to play football every Wednesday on 7th Avenue, one of the main roads in Alexandra. The road was fully blocked for traffic during the afternoon. On the road, there are five improvised street soccer fields with small goals. Somebody drew the goal areas and the centre-spots on the tarmac. We see around one 100 people, mostly male and of all ages, standing around the football pitches. One of the local bars plays loud music that can be heard throughout 
the whole street. Little children run around, people walk in and out their houses and bars on the side of the road. There are some shops and stalls selling food and beverages. On the sideline of one of the fields a coach is smoking a cigarette, while speaking to his players.

The children who are participating in the tournament wear fluorescent vests with the name of Kia written on them. Most of them wear blue shorts and blue football socks, from the local football association. Somebody on the street explains to us that most of the coaches and the children currently playing are members of the Alexandra Local Football Association (ALFA). They were selected through ALFA. Several persons share some standard descriptive information about the programme, such as the number of teams competing and the notion that every team has to consist of four boys and two girls. The children play fanatically and do not seem to be bothered by the small chaos around them.

During our visits we converse mostly with several coaches. A dominant theme in their stories is the (lack of) commitment of Kia to the Street Soccer programme. One of the coaches tells us that he only saw people from Kia the first time: 'And at the end, they come to pick up the materials again' (Anonymous, coach, 18 May 2011). Another coach makes a similar remark: 'We don't see anyone from Kia here on the streets. They just give us the materials and take them away again after eight weeks' (Field note, 20-5).

When these persons elaborate their story about the programme, a narrative structure starts to become visible. A dominant theme that comes forward from these narratives is that Kia is not committed to the goals of the programme nor to the development of critical life skills of youth. Several coaches and a primary school teacher provide examples of this theme. For instance by explaining that the selected youth for the programme already participated in ALFA, meaning that Kia's programme did not help in increasing levels of sport participation. Another example revolved around the aim of developing critical life skills. The coaches were selected by Kia's organising partner, Sporting Chance, based on their personal behaviour. Sporting Chance did educate coaches on football rules, but not on issues such as living a healthy life, good nutrition or goal setting. Furthermore, these coaches, similar to most of the players, already were active in ALFA.

Due to these issues, a feeling of disappointment about the commitment of Kia predominates in these stories. The director of ALFA states: 'We are not benefitting from Kia. For the future it doesn't work. Nothing was left behind. They took everything with them after 8 weeks, like the goals, the balls, everything. The people want to see continuity' (Field note, 20-5).

Continuity, or rather the lack of continuity of the project and ownership of the provided material, is regarded as an important aspect of legacy by locals involved in the programme. Continuity relates to the idea of a desired increase in the level of sport participation as a marker for a livelier and healthier community. Contributing to a healthier community was a goal of the project and is also valued by local citizens. The question of ownership of the sporting equipment relates to the idea of a desired 
increased quality of sport facilities, which was also an explicit goal of the project. These are typical examples of a sport-related tangible legacy (see Chappelet 2012). The desires about legacy brought forward in local residents' stories are not so different from legacy desires of politicians or event organisers. Increased sport participation and better sport facilities for communities are often mentioned as sport mega-event outcomes (Cornelissen et al. 2011). However, the post-event interpretations of local citizens show that creating such outcomes is a local and complex matter.

\section{CONCLUSION AND DISCUSSION}

In conclusion, an analysis of stories about sport mega-events' legacies is missing in current scholarly work on the issue. Current research tends to treat legacy as something separate from local practices and experiences. We argue that these local practices are vital in understanding a sport mega-event's legacies. Inspired by the specific use of the concept in ageing studies, we argued that these local experiences can be captured through collecting and analysing stories by adopting a narrative ethnographic approach.

Stories about the legacy of sport mega-events abound in newspapers, policy documents, official speeches and in communities. Local stories and storytelling practices can provide useful information about the perceived legacies of a sport megaevent. Our study reveals that local residents continually reconstruct their experience of the event and its legacies through their stories. These local stories form a counterweight to official and ceremonial legacy stories, which are told during or at the end of a sport mega-event by those in power. In citizens' stories micro symbolic meanings of legacies of the 2010 FIFA World Cup surpass macro-economic and macro-social legacies. The stories presented a signal positive feeling about the World Cup in general. What has been called the 'feel good-factor' (Bob and Swart 2010) is a form of social legacy that is also applicable to the situation in Alexandra. We conclude that local residents of the township of Alexandra perceive changes in public safety and the image of Alexandra as the most important positive legacy of the 2010 FIFA World Cup. These positive feelings were most dominantly expressed in the beginning of stories about the legacy of the World Cup. The stories show that a negative feeling because of disappointing economic revenue is balanced by the increased feelings of pride and people's perception that they do not feel unnoticed or neglected anymore. In general, stories would begin by addressing one or more of these three themes, before turning to more detailed descriptions of personal experiences or the sport development projects we specifically aimed at in our research. The further stories developed, the more nuanced and critical meanings about the legacy of the World Cup became. This is where stories took a micro perspective, reflecting on personal situations or community structures. At the same time, when stories did describe personal situations in more detail, people took a critical stance towards the World Cup's legacy, because it was felt that personal situations and community structures were often disrupted, rather than improved. Thus, residents' 
stories provide a detailed, nuanced and often paradoxical account on the dimension of intangible and tangible legacies (Chappelet 2012). Therefore, we maintain that meanings about sport mega-event legacies shared through stories are highly situated in their local community practices. Such stories tend to have a very anecdotal and practical character. These anecdotal and practical tales about sport mega-event legacy inevitably touch on sociological concepts, such as power, inequality, symbolic capital, community life and gender. A further analysis of how these concepts are understood in stories about sport mega-event legacies was outside the scope of this paper, but is much needed to better understand the perceived societal impact of sport mega-events on local communities.

As for the sport-for-development projects, our analysis shows that local residents are critical towards the organisations responsible for the projects. It was felt that both FIFA and Kia used and disrupted existing local sport and development structures. This should warn local NGOs against becoming too eager to leverage the promotional opportunities of mega-events (Darnell 2012). Overestimating the opportunities a sport mega-event may provide in building acceptance and maintaining access to funding might lead to disappointing results in terms of organisational autonomy, continuity and local support itself.

Our argument is that a narrative ethnographic approach provides extensive accounts about sport mega-event legacies, which help to better understand the different faces of sport mega-events' legacies at a micro level. Our approach shows local inhabitants make sense of and give meaning to the legacy of a sport mega-event through their stories. Similar to conclusions drawn by Hunter and Rowles (2005), we stress that residents' stories not only provide an interpretation of legacy, but also share a moral account of it; they highlight both 'good' and 'bad' aspects of the legacy of the 2010 FIFA World Cup and provide a personal evaluation. We agree with Lienhard and Preuss (2014) that such moral accounts- that is, the meaning of legacies of a sport mega-event held by diverse stakeholders- change over time. Analysing stories, then, sheds light on the locality and complexity of sport mega-event legacy. The approach helps in grasping paradoxical ways in which legacy is interpreted. Such paradoxical interpretations ultimately show that the macro-level analyses of sport mega-event legacy cannot readily be transferred to local situations. In addition, local residents focus their stories about legacy on local aspects, such as the accessibility of a nearby sport facility. Such local interpretations of legacy seem far removed from scholarly interpretations of sport mega-event legacy. Our approach, then, adds a detailed analysis of the messiness, many-sidedness, complexity and conflicting nature of sport mega-event legacy. It highlights the central role stories can play in the further understanding of sport mega-event legacy.

However, an ethnographic narrative approach also has its limitations. While it may be strong in capturing the lived experience of local inhabitants, and showing the complexity of sport mega-event legacy, it is weak in establishing the legacy. A narrative analysis provides interpretive knowledge about the way people make sense of a certain phenomenon, it does not provide positivist, predictive knowledge about the legacy of 
sport mega-events. Precisely because of its contextual nature, a narrative ethnographic approach cannot add to such generalisable intentions. Another limitation of this research is the chosen timeframe. The study took place one year after the event, which is still a relatively short period after the event to research legacy. However, if inhabitants understand certain local phenomena, such as the way a sport-for-development project is organised as part of the legacy of a sport mega-event, then this legitimates researching legacy at that point in time. Future research could compare short-term and long-term stories in order to be able to determine lasting elements of legacy stories. This could provide sport mega-event organisers and their partners with valuable information about what matters at the local level.

Acknowledging these issues of critique on a narrative ethnographic approach, we argue that sport mega-events' legacies should, in addition to other approaches, be understood through an interpretive lens involving local stories about legacies. Such an approach helps in understanding the complexity of legacies of sport mega-events and the way these events influence local lives and communities. This article has shown that analysing stories about (the lived experience of) the legacy of sport mega-events in local communities contributes to understanding how legacy is perceived locally and how this perception contributes to reconstructing the legacy itself.

\section{ACKNOWLEDGEMENTS}

The authors would like to thank the two other members of the local research team, Sarah de Bakker and Lambert Wassink, for making their field notes available for this article.

\section{REFERENCES}

Agha, N., Fairley, S. \& Gibson, H. 2012. Considering legacy as a multi-dimensional construct: The legacy of the Olympic Games. Sport Management Review 15: 125-139.

Alegi, P. \& Bolsmann, C. (eds.). 2013. Africa's World Cup: Critical reflections on play, patriotism, spectatorship, and space. Ann Arbor: University of Michigan Press.

Anonymous, coach, Alexandra, Johannesburg, 18 May 2011.

Anonymous, local bar owner, Alexandra, Johannesburg, 18 May 2011.

Anonymous, student community journalism centre, Alexandra, Johannesburg, 20 May 2011.

Anonymous, volunteer community centre, Alexandra, Johannesburg, 11 May 2011.

Anonymous, volunteer community centre, Alexandra, Johannesburg, 20 May 2011.

Ayanda, former volunteer of Play Soccer South Africa, Alexandra, Johannesburg, 31 May 2011

Ben, S. 2013. World Cup legacy centre opens. Alex News, 13 November. Retrieved from http:// alexnews.co.za/16787/world-cup-legacy/ (accessed 10 March 2014).

Bob, U. \& Swart, K. 2010. Sport events and social legacies. Alternation 17(2): 72-95. 
Bohlmann, H.R. \& Van Heerden, J.H. 2005. The impact of hosting a major sport event on the South African economy. Working paper. Pretoria: University of Pretoria.

Burgan, B. \& Mules, T. 1992. Economic impact of sporting events. Annals of Tourism Research 19(4): $700-710$.

Cashman, R. 2003. What is Olympic legacy?. In M. de Moragas et al. (eds.), The legacy of the Olympic Games, 1984-2002. Lausanne: International Olympic Committee.

Chalkley, B. \& Essex, S. 1999. Urban development through hosting international events: A history of the Olympic Games. Planning Perspectives 14(4): 369-394.

Chappelet, J. 2012. Mega sporting event legacies: a multifaceted concept. Papeles de Europa 25: $76-86$.

Chen, K.K., 2012. Storytelling: An informal mechanism of accountability for voluntary organizations. Nonprofit and Voluntary Sector Quarterly 42(5): 902-922.

Cottle, E. (ed.). 2011. South Africa's World Cup: A legacy for whom? Scottsville: University of KwaZulu-Natal Press.

Cornelissen, S., Bob, U. \& Swart, K. 2011. Towards redefining the concept of legacy in relation to sport mega-events: Insights from the 2010 FIFA World Cup. Development Southern Africa 28(3): 307-318.

Curi, M., Knijnik, J. \& Mascarenhas, G. 2011. The Pan American Games in Rio de Janeiro 2007: Consequences of a sport mega-event on a BRIC country. International Review for the Sociology of Sport 46(2): 140-156.

Czeglédy, A.P. 2009. Urban dreams: The 2010 Football World Cup and expectations of benefit in Johannesburg. In U. Pillay et al. (eds.), Development and dreams: The urban legacy of the 2010 Football World Cup. Cape Town: HSRC Press.

Darnell, S.C. 2012. Sport for development and peace. A critical sociology. London: Bloomsbury Academic.

Dimeo, P. \& Kay, J. 2004. Major sport events, image projection and the problems of the 'Semiperiphery': A case study of the 1996 South Asia Cricket World Cup. Third World Quarterly 25(7): $1263-1276$.

Doherty, A. 2009. The volunteer legacy of a major sport event. Journal of Policy Research in Tourism, Leisure and Events 1(3): 185-207.

Doherty, K. 2013. Cape Town, the city without and within the while lines. In Alegi, P. \& Bolsmann, C. (eds.), Africa's World Cup: Critical Reflections on Play, Patriotism, Spectatorship, and Space. Ann Arbor: University of Michigan Press.

Fischer, F. 2003. Reframing public policy. Discursive politics and deliberative practices. Oxford: Oxford University Press.

Freeman, M. 1993. Rewriting the self. History, memory, narrative. London, New York: Routledge.

Freeman, M. 2002. The presence of what is missing: Memory, poetry and the ride home. In R.J. Pellegrini \& T.R. Sarbin (eds.), Critical incident narratives in the development of men's lives. New York: Haworth Clinical Practice Press.

Grassroot Soccer 2013. Grassroot Soccer and the 2010 World Cup. Cape Town: Grassroot Soccer. Retrieved from http://www.grassrootsoccer.org/where-we-work/south-africa/ (accessed 10 March 2014). 
Gratton, C. \& Preuss, H. 2008. Maximizing Olympic impacts by building up legacies. The International Journal of the History of Sport 25(14): 1922-1938.

Hae-joang, C.H. 2004. Beyond the FIFA's World Cup: An ethnography of the 'local' in South Korea around the 2002 World Cup. Inter-Asia Cultural Studies 5(1): 8-25.

Heere, B., et al. 2013. The power of sport to unite a nation: the social value of the 2010 FIFA World Cup in South Africa. European Sport Management Quarterly 13(4): 450-471.

Horne, J. 2004. The global game of football. 2002 World Cup and regional development in Japan. Third World Quarterly 25(7): 1233-1244.

Hunter, E.G. 2007. Beyond death: Inheriting the past and giving to the future, transmitting the legacy of one's self. Journal of Death and Dying 56(4): 313-329.

Hunter, E.G. \& Rowles, G.D. 2005. Leaving a legacy: Toward a typology. Journal of aging studies 19: 327-347.

Kim, H., Gurosy, D. \& Lee, S.B. 2006. The impact of the 2002 World Cup on South Korea: Comparisons of pre and post games. Tourism Management 27(1), 86-96.

Kim, S.S. \& Petrick, J.F. 2005. Residents' perceptions on impacts of the FIFA 2002 World Cup: The case of Seoul as a host city. Tourism Management 26(1): 25-38.

Lee, C. \& Taylor, T. 2005. Critical reflections on the economic impact assessment of a mega-event: The case of 2002 FIFA World Cup. Tourism Management 26(4): 595-603.

Lienhard, P. \& Preuss, H. 2014. Legacy, sustainability and CSR at mega sport events: An analysis of the UEFA EURO 2008 in Switzerland. Wiesbaden: Springer Gabler.

Local bar owner, Alexandra, Johannesburg, 18 May 2011.

Maisha, president Alexandra Local Football Association, Alexandra, Johannesburg, 20 May 2011

Misener, L. \& Mason, D.S. 2009. Fostering community development through sporting events strategies: An examination of urban regime perceptions. Journal of Sport Management 23: 770-794.

Moodley, R. Police Officer, Alexandra, Johannesburg, 25 May 2011.

Moore, S.L., Metcalf, B. \& Schow, E. 2006. The quest for meaning in ageing. Geriatric Nursing 27(5): 293-299.

Moshe, coordinator during the Football for Hope Festival, Alexandra, Johannesburg, 11 May 2011

Newton, C. 2009. The reverse side of the medal: About the 2010 FIFA World Cup and the beautification of the N2 in Cape Town. Urban Forum 20: 93-108.

Ngwenya, L. Director Bid Book Compliance 2010 City of Johannesburg, Johannesburg, 1 June 2011.

Polkinghorne, D.E. 2000. Narrative knowing and the study of lives. Aging and biography: Explorations in adult development. New York: Springer Publishing Company.

Preuss, H. 2007. The conceptualisation and measurement of mega sport event legacies. Journal of Sport \& Tourism 12(3-4): 207-228.

Riessman, C.K. 2008. Narrative methods for the human sciences. Thousand Oaks: Sage.

Schausteck de Almeida, B., Bolsmann, C., Marchi Júnior, W. \& Souza, J. 2013. Rationales, rhetoric and realities: FIFA's World Cup in South Africa 2010 and Brazil 2014. International Review for the Sociology of Sport, doi: 10.1177/1012690213481970.

Schwartz-Shea, P. \& Yanow, D. 2012. Interpretive research design. New York: Routledge. 
Sporting Chance 2013. KIA Street Soccer 2013. Street Soccer kicks of around the country. Cape Town: Sporting Chance. Retrieved from http://www.sportingchance.co.za/projects/street-soccer/ (accessed 10 March 2014).

Student, community journalism centre, Alexandra, Johannesburg, 20 May 2011.

Van Hulst, M. 2013. Storytelling at the police station: The canteen culture revisited. British Journal of Criminology 53: 624-642.

\section{BIOGRAPHICAL NOTES}

Maikel Waardenburg is a lecturer in organisational science at Utrecht University, School of Governance.

Marjolein van den Bergh worked as junior research assistant at Utrecht University, School of Governance. She currently works as policy advisor for the same institute.

Frank van Eekeren is senior consultant at Utrecht University, School of Governance. 